\title{
PENGARUH EMISI OBLIGASI \\ TERHADAP PENDAPATAN SEWA MODAL DENGAN PENDEKATAN MODEL DINAMIS AUTOREGRESSIVE PADA PT. PEGADAIAN (PERSERO)
}

\author{
Elly Soraya Nurulhuda \\ Anis Lutfiati \\ Oktarian Trisna Purnama \\ Program Studi Manajemen Fakultas Ekonomi dan Bisnis \\ Universitas Islam As-Syafi'iyah \\ sorayaelly@gmail.com \\ anis.lutfiati@gmail.com
}

\begin{abstract}
This study aims to determine the effect of Bond Issuance Value on Capital Lease Income at PT. Pegadaian (Persero). The sample used in this research is the financial statements of PT. Pegadaian that issued bonds in 2007, 2009, 2011, 2012, 2013, 2014, 2015, 2017 and 2018. The independent variable of this study is the value of the bond issuance. The dependent variable is capital rental income. The analysis used is an autoregressive dynamic model with the Koyck approach. The results show that the value of bond issuance and capital lease income from the previous year has a significant effect on capital rental income.
\end{abstract}

Keywords: Bond Issuance Value, Capital Lease Income, Autoregressive, Koyck

\begin{abstract}
ABSTRAK
Penelitian ini bertujuan untuk mengetahui pengaruh Emisi Obligasi terhadap Pendapatan Sewa Modal Dengan Pendekatan Model Dinamis Autoregressive pada PT. Pegadaian (Persero). Sampel yang digunakan dalam penelitian adalah laporan keuangan PT. Pegadaian yang melakukan emisi obligasi yaitu tahun 2007, 2009, 2011, 2012, 2013, 2014, 2015, 2017 dan 2018. Variabel independen penelitian ini adalah nilai emisi obligasi. Variabel dependen yaitu pendapatan sewa modal. Analisis yang digunakan adalah model dinamis autoregressive dengan pendekatan Koyck. Hasilnya menunjukkan bahwa nilai emisi obligasi tidak berpengaruh terhadap pendapatan sewa modal dan pendapatan sewa modal tahun sebelumnya berpengaruh signifikan terhadap pendapatan sewa modal.
\end{abstract}

Kata Kunci: Emisi Obligasi, Pendapatan Sewa Modal, Autoregressive, Koyck 


\section{PENDAHULUAN}

\section{Latar Belakang}

Setiap perusahaaan menginginkan perusahaannya maju dan berkembang. Banyak cara yang dapat dilakukan perusahaan agar mampu mengembangkan perusahaannya. Pengembangan perusahaan juga dapat disebut dengan ekspansi usaha.

Biasanya, sebuah perusahaan melakukan ekspansi apabila perusahaan sudah berjalan dengan baik dan stabil. Dalam melaksanakan ekpansi usaha, perusahaan membutuhkan tambahan dana untuk memperluas jaringan yang dapat meningkatkan usahanya. Sumber dana untuk melakukan ekspansi usaha dapat berasal dari dalam perusahaan maupun dari luar perusahaan (Sattar, 2017). Sumber dana yang berasal dari eksternal perusahaan antara lain dengan menerbitkan obligasi.

Ekspansi usaha juga tergantung pada produk perusahaan itu sendiri. Seperti perusahaan jasa pembiayaan pada PT. Pegadaian (Persero), Ekspansi usaha yang dilakukan oleh PT Pegadaian (Persero) adalah dengan menambah Unit Pelayanan Cabang, Unit Pelayanan Syariah dan juga modal kerja yang disewakan untuk produk Kredit Cepat Aman (KCA). Dengan semakin banyaknya modal untuk membiayai nasabah, maka PT. Pegadaian (Persero) semakin mampu untuk menerima calon nasabah yang ingin melakukan pinjaman di PT. Pegadaian (Persero), sehingga pendapatan sewa modalnya meningkat.

Berikut ini merupakan data Ekspansi Usaha yang diukur dengan Pendapatan Sewa Modal PT. Pegadaian (Persero) pada tahun penerbitan Obligasi.

\section{Grafik 1.}

Perkembangan Pendapatan Sewa Modal PT. Pegadaian (Persero) pada Tahun Emisi Obligasi 2007-2018

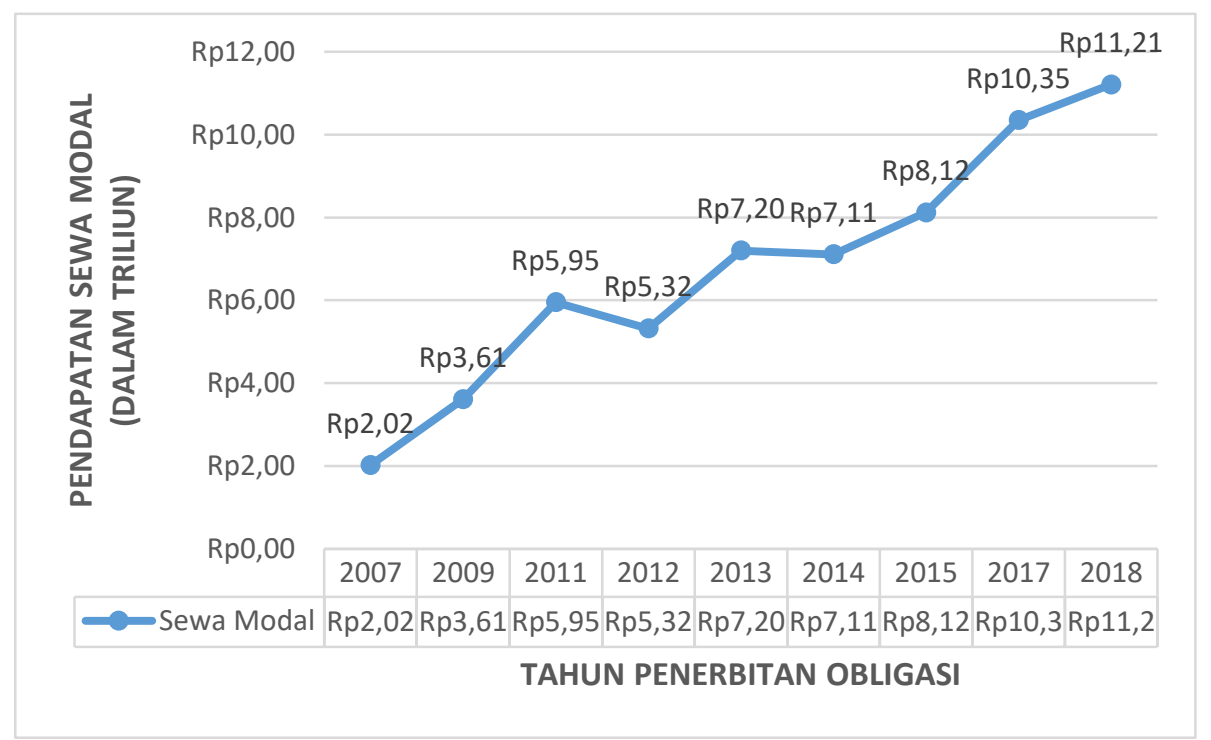

Sumber: Annual Report PT. Pegadaian (Persero) 
Pada grafik 1 terjadinya fluktuasi (naik-turun) pendapatan sewa modal PT. Pegadaian (Persero) pada tahun emisi obligasi. Pada emisi obligasi tahun 2012 dan 2014, pendapatan sewa modal PT Pegadaian (Persero) mengalami penurunan dibanding tahun emisi obligasi sebelumnya. Kemudian pada emisi tahun 2015 mengalami peningkatan, sehingga total pendapatan sewa modal sebesar Rp 8,12 Triliun. dan seterusnya pada emisi selanjutnya mengalami peningkatan. Hingga pada tahun emisi terakhir, pendapatan sewa modal PT Pegadaian (Persero) sebesar Rp. 11,21 Triliun.

Perubahan pendapatan sewa modal pada PT. Pegadaian (Persero) disebabkan oleh beberapa faktor, antara lain struktur modal perusahaan itu sendiri. Untuk meningkatkan struktur modal perusahaan, perusahaan memerlukan tambahan dana untuk mencapai tujuan tertentu atau untuk melakukan peningkatan kualitas perusahaan dengan melakukan ekspansi usaha.

Secara umum, sumber penambahan dana perusahaan dapat dilakukan dengan dua sumber alternative, yaitu sumber pendanaan internal dan juga eksternal (Fahmi, 2014). Sumber pendanaan internal berasal dari modal perusahaan itu sendiri sedangkan pendanaan yang bersumber dari eksternal dapat berasal dari penjualan saham dan pinjaman dana oleh umum atau berhutang. Pendanaan dengan berhutang yang diterbitkan oleh Bursa Efek Indonesia kepada masyarakat umum dapat disebut dengan Obligasi.

\section{Grafik 2.}

Emisi Obligasi PT. Pegadaian (Persero) Tahun 2007-2018

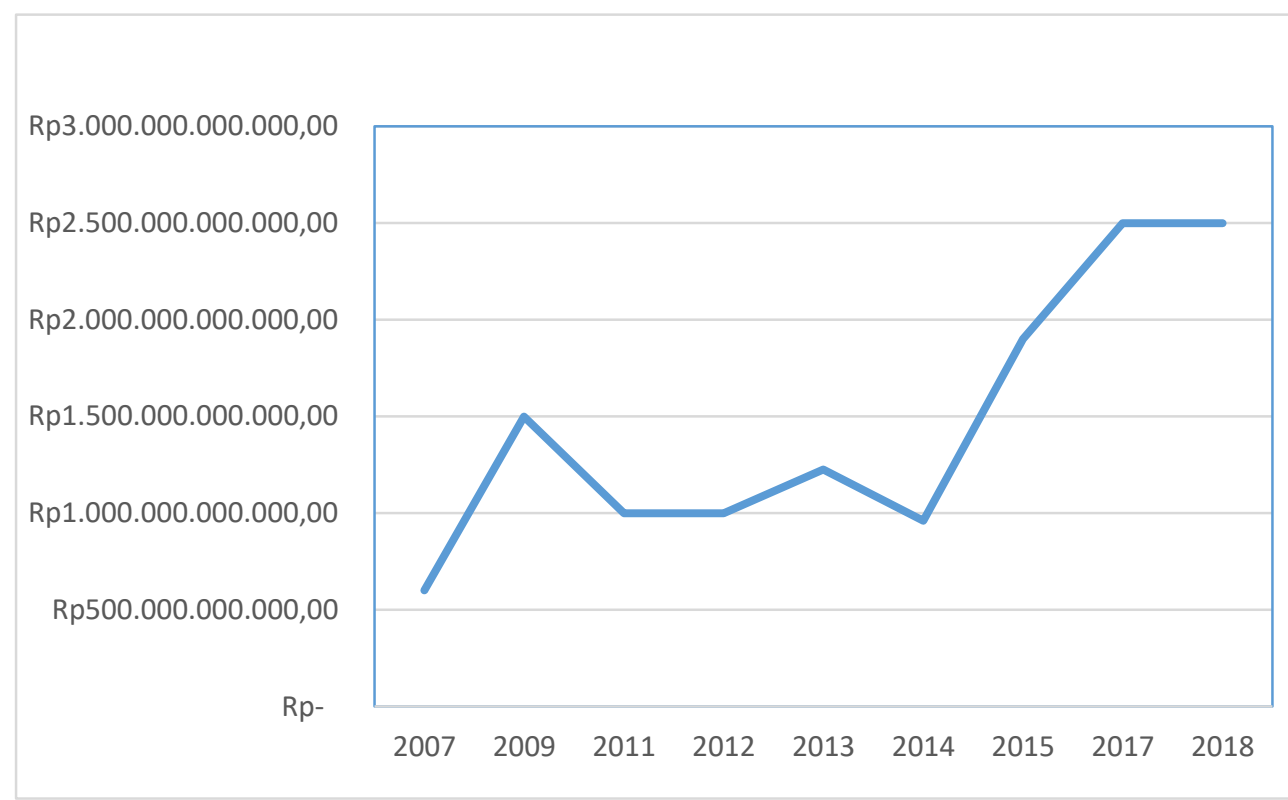

Sumber: Laporan Keuangan PT. Pegdaian (Persero) 
Dari grafik 2 dapat dilihat nilai emisi obligasi PT. Pegadaian (Persero) dari tahun 2007 sampai tahun 2019. PT. Pegadaian tidak melakukan penerbitan nilai obligasi setiap tahun, dilihat dari grafik emisi obligasi tahun 2007, 2009, 2011, 2012, 2013, 2014, 2015, 2017 dan 2018. Emisi Obligasi yang dilakukan PT. Pegadaian (Persero) dengan jumlah yang berbeda setiap tahun penerbitan dilihat dari kebutuhan PT. Pegadaian (Persero) itu sendiri. Seperti dilansir pada Bisnis.com (8/5/2020) oleh Finna menyampaikan bahwa kebutuhan emiten untuk refinancing utang menjadi factor utama mandat rencana emisi obligasi di tengah pandemic covid-19. Associate Director of Research and Investmen Pilarmas Sekuritas Maximilianus Nico Demus mengatakan bahwa restrukturisasi merupakan salah satu hal yang paling diminati oleh emiten saat ini. Hal tersebut dikarenakan emiten berupaya untuk menjaga likuiditas jangka pendek tetep prima di tengah prospek perlambatan ekonomi akibat covid-19.

\section{Perumusan Masalah}

1) Apakah terdapat pengaruh Emisi Obligasi terhadap Pendapatan Sewa Modal pada PT. Pegadaian (Persero) dan 2) Apakah terdapat pengaruh Pendapatan Sewa Modal tahun sebelumnya terhadap Pendapatan Sewa Modal pada PT. Pegadaian (Persero).

\section{Tujuan Penelitian}

1) Mengetahui pengaruh Emisi Obligasi terhadap Pendapatan Sewa Modal pada PT. Pegadaian (Persero) dan 2) Mengetahui pengaruh pendapatan sewa modal tahun sebelumnya terhadap Pendapatan Sewa Modal pada PT. Pegadaian (Persero).

\section{Manfaat Penelitian}

1) Sebagai dasar memperluas penelitian khususnya tentang pengaruh emisi obligasi terhadap ekspansi bisnis dan profitabilitas perusahaan dan 2) Dapat menjadi pertimbagan untuk perusahaan dalam menerbitkan obligasi yang bertujuan untuk mendapatkan tambahan dana.

\section{TINJAUAN PUSTAKA DAN HIPOTESIS}

\section{Bisnis Pegadaian}

Pergadaian dan Pegadaian merupakan suatu kata yang mirip namun memiliki makna yang berbeda. Pergadaian merupakan kegiatan memberi pinjaman uang dengan jaminan barang berharga. Dalam Kamus Besar Bahasa Indonesia (KBBI) Pergadaian berasal dari kata Gadai yang artinya meminjam uang dngan dalam batas waktu tertentu dengan menyerahkan barang sebagai tanggungan, jika telah sampai pada waktunya barang tidak ditebus, akan menjadi hak si pemberi pinjaman. Sedangkan pegadaian sebagai lembaga pembiayaan atau perkreditan non bank dengan system gadai. PT. Pegadaian adalah satu-satunya lembaga pembiayaan non bank dengan system gadai dibawah naungan kementrian BUMN. Dalam www.okezone.com (27/08/2020) oleh 
Karina menulis bahwa R. Swasono Amoeng Widodo mengatakan Pegadaian adalah sebuah nama merk (Brand) PT. Pegadaian (Persero), perusahaan BUMN berstatus perusahaan perseroan yang melakukan bisnis sebagaimana diatur dalam Peraturan Otoritas Jasa Keuangan (POJK) No.31/POJK.05/2016. Bahkan nama dan logo Pegadaian telah tercatat sebagai hak atas karya intelektual PT. Pegadaian (Persero) sejak tahun 2009 dan telah diperpanjang pada tahun 2019 untuk 10 tahun ke depan.

Fungsi dan tujuan pegadaian secara umum sebagai berikut: : a) Menciptakan dan mengembangkan usaha-usaha lain yang menguntungkan bagi pegadaian maupun kepada masyarakat, b) Mengelola penyaluran uang pinjaman atas dasar hukum gadai dengan cara mudah, cepat, aman dan hemat, c) Mengelola keuangan, perlengkapan, kepegawaian, pendidikan dan pelatihan, d) Melakukan penelitian dan pengembangan serta mengawasi pengelolaan pegadaian, e) Mengelola organisasi, tata kerja, dan tata laksana pegadaian, f) Membina pola perkreditan agar benar-benar terarah dan bermanfaat, dan g) Berperan serta dalam mencegah adanya pemberian pinjaman yang tidak wajar, pegadaian gelap dan riba (Mulazid, 2016)

Dengan demikian tugas pokok bisnis pegadaian memberikan pinjaman uang pada masyarakat dengan system gadai. Hal ini bertujuan untuk meningkatkan masyarakat kecil, UMKM, untuk mencegah rentenir yang memberikan pinjaman dengan bunga yang tinggi.

\section{Obligasi}

Obligasi atau yang disebut dengan Bonds adalah salah satu bentuk surat berharga jangka panjang berbentuk pernyataan hutang yang diterbitkan untuk ditawarkan kepada publik oleh perusahaan maupun negara dalam rangka untuk memperoleh tambahan dana. Pasar Modal ialah tempat transaksi surat berharga tersebut. Banyak produk yang diperjual-belikan di pasar modal, namun yang paling banyak ialah Saham dan Obligasi (Fahmi, 2014). Maka dari itu, obligasi dapat dilihat dari dua sisi, sisi investor dan juga sisi penerbit obligasi (emiten). Bagi investor, obligasi merupakan sekuritas yang berpendapatan tetap sepanjang usia obligasi, sedangkan bagi emiten, emisi obligasi adalah suatu cara yang untuk memperoleh tambahan dana dari investor dan menjadi sebuah pembiayaan bagi emiten, karena adanya tingkat bunga (kupon) yang harus diberikan kepada investor oleh emiten obligasi (Ekananda, 2019).

Sekuritas ini merupakan sekuritas yang paling banyak diminati oleh calon investor yang tidak menyukai resiko. Karena pemegang obligasi (investor) akan mendapatkan pendapatan tetap berupa bunga yang dibayarkan oleh emiten obligasi. Akan tetapi, pemegang obligasi ini tidak menjadi kepemilikan bagi perusahaan yang menerbitkan obligasi. Berbeda dengan saham, barang siapa yang memiliki saham, berarti pemegang saham tersebut termasuk dari pemilik perusahaan yang menjual saham tersebut. Oleh sebab itu, dalam pasar modal, tidak ada perusahaan yang melakukan penjualan obligasi, 
melainkan penawaran obligasi. Karena kata penjualan lebih cocok untuk instrument pasar modal yang lain, seperti saham.

Bagi emiten obligasi, memberikan sebuah kepercayaan pada calon investor bukanlah hal yang mudah. Pemahaman tentang jenis-jenis obligasi juga memberikan kontribusi yang spesifik pada risiko obligasi yang akan dipilih oleh calon investor.

\section{Tujuan Emisi Obligasi}

Keputusan penerbitan obligasi ini merupakan keputusan yang strategis bagi manajemen perusahaan. Karena pencairan dana dari emisi obligasi ini sekaligus, tidak melalui termin-termin (Fakhruddin, 2013). Pihak manajemen tidak sembarangan dalam melakukan keputusan ini, melainkan sudah melakukan perhitungan yang tepat untuk apa dana yang diperoleh dari emisi obligasi ini. Bagi perusahaan, pencairan dana dari emisi obligasi merupakan dana segar yang diterima perusahaan. Dana tersebut nantinya akan digunakan perusahaan untuk memenuhi kewajiban jangka pendek perusahaan, memperbaiki struktur pendanaan perusahaan, meningkatkan kinerja perusahaan, atau bahkan untuk ekspansi bisnis.

Obligasi diterbitkan memiliki legalitas dari segi hukum, karena mempunyai pertanggung jawaban bila ada ketidakmampuan menyelesaikannya kewajibannya.

Fahmi (2014:414) mengatakan bahwa: Ada beberapa pihak yang dapat melakukan emisi obligasi: 1) Pemerintah, 2) Pemerintah Daerah, 3) Pemerintah Asing, 4) Perusahaan dan 5) Perusahaan Asing

Alasan perusahaan melakukan emisi obligasi : 1) Penetapan bunga obligasi biasanya tidak terlalu tinggi, 2) Biaya penerbitan obligasi lebih murah dibandingkan saham, 3) Saat obligasi ditawarkan jika terjadi kendala pembayaran obligasi, perusahaan dapat mengalihkan pemegang obligasi menjadi pemegang saham, dengan obligasi konversi

\section{4.. Yield Obligasi}

Pendapatan invesatasi obligasi dapat diukur dengan imbal hasil (Yield). Bagi calon investor, imbal hasil ini salah satu faktor pertimbangan untuk melakukan investasi obligasi. Ekananda (2019:249) Terdapat sejumlah pendekatan yang dapat digunakan untuk mengukur imbal hasil dan setiap ukuran imbal hasil tersebut memiliki manfaat tersendiri bagi investor untuk digunakan sebagai salah satu alat dalam mengambil keputusan investasi pada sekuritas obligasi (Ekananda,2019;249)

Pemahaman yang baik tentang imbal hasil obligasi bagi investor akan memberikan informasi yang baik bagi penilaian obligasi yang diminati. Adapun bentukbentuk ukuran imbal hasil sebagai berikut: 1) Imbal Hasil Kupon, merupakan ukuran dari besaran imbal hasil kupon yang diperoleh oleh investasi obligasi terhadap nilai obligasi, 2) Imbal Hasil Aktual (Current Yield) adalah model perhitungan imbal hasil aktual dari suatu obligasi terhadap nilai pasar obligasi, 3) Imbal Hasil Hingga Jatuh Tempo (Yield to 
Maturity), model perhitungan imbal hasil guna mengukur jumlah imbal hasil yang diperoleh investor pada saat jatuh tempo obligasi mencakup imbal hasil kupon, nilai nominal obligasi dan nilai pasar obligasi, 4) Imbal Hasil Saat Dibeli Kembali (Yield to Call) adalah model perhitungan imbal hasil pada obligasi yang dapat dibeli kembali oleh emiten sebelum tanggal jatuh tempo dan 5) Imbal Hasil dengan Tingkat Bungan Mengambang adalah model perhitungan imbal hasil obligasi yang menggunakan bunga kupon mengambang (Ekananda, 2019).

\section{Hipotesis}

\section{a. Pengaruh nilai emisi obligasi terhadap pendapatan sewa modal}

Ekspansi usaha merupakan cara perusahaan agar dapat meningkatkan nilai perusahaanya. Banyak cara yang termasuk dalam kegiatan ekspansi usaha antara lain meningkatkan kualitas produk perusahaan, melakukan merger dan akuisisi. PT. Pegadaian melakukan ekspansi usahanya antara lain dengan meningkatkan kuliatas produk jasa yaitu Kredit Cepat Aman (KCA). Dalam melakukan pengembangan produk jasa ini, PT. Pegadaian membutuhkan tambahan modal usaha. Salah satu cara untuk memperoleh tambahan modal usaha tersebut dengan melakukan emisi obligasi.

Obligasi termasuk tambahan dana eksternal, yang artinya diperoleh dengan pinjaman. Fahmi (2014:186). Oleh sebab itu, pengelolaan dana ini sangat berpengaruh terhadap hasil kegiatan usaha perusahaan. Semakin besar modal usaha maka PT. Pegadaian semakin mampu membiayai lebih banyak calon nasabah yang nantinya akan meningkatkan pendapatan sewa modal. Menurut Maimnah (2018) Terdapat pengaruh emisi Obigasi Syariah terhadap ROE, dan tidak terapat pengaruh Reksadana terhadap ROE. Maka dapat dinyatakan bahwa Emisi Obligasi mempunyai pengaruh terhadap pendapatan sewa modal.

\section{b. Pengaruh pendapatan sewa modal tahun sebelumnya terhadap pendapatan sewa modal}

Salah satu dalam melakukan pengembangan usaha ialah memerlukan tambahan modal. Tambahan modal untuk melakukan ekspansi usaha dapat berasal dari dalam perusahaan atau luar perusahaan (Sattar, 2017). Sumber modal dari dalam perushaan dapat berupa laba ditahan. Sedangkan sumber modal dari luar luar perusahaan, seperti menerbitkan obligasi dan pinjaman ke bank (Fahmi, 2014).

Pengembangan usaha yang dilakukan bergantung pada modal perusahaan. jika modal perusahaannya kuat, maka kemungkinan tujuan pengembangan perusahaan akan tercapai. Joel G. Siegel dan Jae K. (Fahmi ,2014:175). Menurut Dilla (2019), pembiayaan KCA yang disalurkan setiap tahun mulai tahun 2013 sampai 2017 mengalami peningkatan namun tidak sejalan dengan meningkatnya pendapatan sewa modal yang diterima oleh PT.Pegadaian (Persero) Cabang Pringgan. Maka dinyatakan Pendapatan Sewa Modal tahun sebelumnya mempunyai pengaruh terhadap Pendapatan Sewa Modal 


\section{METODE PENELITIAN}

\section{Populasin dan Sample Penelitian}

Populasi penelitian ini adalah laporan keuangan PT. Pegadaian (Persero) pada tahun-tahun melakukan emisi obligasi, tahun 2007, 2009, 2011, 2012, 2013, 2014, 2015, 2017 dan 2018, populasi dan samplenya penelitian ini laporan keuangan PT. Pegadaian pada tahun-tahun melakukan emisi obligasi.

\section{Metode Analisis Data}

Teknik analisis data dalam penelitian ini adalah analisis Model Dinamis, pengujian asumsi klasik dan pengujian hipotesis. Alat pengelolaan data dengan Software Microsoft Excel dan SPSS 20. Dengan menggunakan 1) Analisis Statistik Deskriptif, 2) Estimasi Model Dinamis dengan menggunakan lag pada variabel dependen di antara variabel independen lainnya disebut dengan model Autoregressive. $\mathrm{Y}_{\mathrm{t}}=\alpha+\beta_{0} \mathrm{X}_{\mathrm{t}}+\gamma \mathrm{Y}_{\mathrm{t}}$ $1+\mu_{\mathrm{t}}$. (Wardhono et al., 2019). Untuk mengetahui dan mendapatkan estimasi parameter model dinamis autoregressive ialah menggunakan transformasi atau pengestimasian model Koyck. Dimana parameter variabel Yt adalah data Pendapatan Sewa Modal pada tahun emisi obligasi yakni 2007, 2009, 2011, 2012, 2013, 2014, 2015, 2017 dan 2018. Xt adalah data Emisi Obligasi pada tahun seperti sebelumnya. Yt-1 adalah data pendapatan sewa modal tahun sebelumnya pada tahun emisi obligasi., 3) Pengujian Signifikansi Parameter, dengan secara simultan. Pada model dinamis dengan pendekatan Koyck secara simultan dilakukan menggunakan statistik uji F dengan taraf signifikansi $\alpha=5 \%$, 4). Selain pengujian signifikansi parameter dilakukan uji koefisien determinasi. Koefisien determinasi diartikan sebagai persen variasi variabel terikat yang dijelaskan atau diperhitungkan oleh variabel bebas. Variabel determinasi dapat dihitung melalui informasi yang diperoleh pada tabel ANOVA (Kuncoro, 2013), 4) Uji Asumsi Klasisk : Uji Normalitas dan Uji Autokorelasi dan 5) Uji hipotesis : Uji t.

\section{HASIL DAN PEMBAHASAN}

\section{Hasil Uji}

a. Analisis Statistik Deskriptif

Dalam melakukan analisis, deskripsi data dari variable penelitian diperlukan untuk memperjelas variabel penelitian. Maka dalam penelitian ini disajikan data penelitian yang terdiri dari Pendapatan Sewa Modal, Nilai Emisi Obligasi dan Pendapatan Sewa Modal tahun sebelumnya. Masing-masing dari data tersebut diolah dengan Microsoft Excel dan SPSS 20.

\section{1) Data Pendapatan Sewa Modal}

Ekspansi Usaha pada penelitian ini diukur dengan pendapatan sewa modal. Karena dana hasil dari penerbitan obligasi diharapkan mampu memperluas basis nasabah 
sehingga mampu membiayai nasabah lebih banyak, dengan demikian dapat meningkatkan pendapatan sewa modal. Pendapatan Sewa Modal merupakan perhitungan keuntungan dari produk jasa pembiayaan. Berikut pendapatan sewa modal pada tahun penerbitan obligasi.

Tabel 1

Data Pendapatan Sewa Modal

PT. Pegadaian (Persero)

\begin{tabular}{|c|c|}
\hline Tahun Emisi Obligasi & $\begin{array}{c}\text { Pendapatan Sewa Modal } \\
\text { (Rupiah) }\end{array}$ \\
\hline 2007 & $2,015,965,793,689$ \\
\hline 2009 & $3,609,785,546,431$ \\
\hline 2011 & $5,953,201,577,601$ \\
\hline 2012 & $5,324,946,956,207$ \\
\hline 2013 & $7,201,410,208,148$ \\
\hline 2014 & $7,113,126,058,127$ \\
\hline 2015 & $8,119,794,619,825$ \\
\hline 2017 & $10,353,521,000,000$ \\
\hline 2018 & $11,205,418,000,000$ \\
\hline
\end{tabular}

Sumber: Laporan Keuangan PT. Pegadaian (Persero)

Tabel 2

Hasil Data Statistik Deskriptif Pendapatan Sewa Modal PT. Pegadaian (Persero)

Descriptive Statistics

\begin{tabular}{|c|c|c|c|c|c|}
\hline & $\mathrm{N}$ & Minimum & Maximum & Mean & Std. Deviation \\
\hline Pendapatan Sewa & 0 & $2,015,965,793,6$ & $11,205,418,000$ & $6,766,352,195,5$ & $2,957,688,417,4$ \\
\hline Modal & & 89.00 & 000.00 & 58.6680 & 67.44780 \\
\hline Valid N (listwise) & 9 & & & & \\
\hline
\end{tabular}

Sumber: Hasil Pengolahan data SPSS 20, 2020

Dari tabel di atas dapat dilihat nilai minimum pendapatan modal sebesar Rp 2.015.965.793.689 dan nilai maksimumnya sebesar Rp 11.205.418.000.000. Kemudian nilai mean menunjukkan bahwa rata-rata pendapatan sewa modal di tahun penerbitan obligasi sebesar Rp. 6.776.352.195.558,6680. Data pendapatan sewa modal terdistribusi normal karena nilai standar deviasinya lebih kecil daripada nilai mean yaitu $2,957,688,417,467.44780$ 


\section{2) Data Nilai Emisi Obligasi}

Emisi obligasi merupakan suatu keputusan perusahaan dalam rangka memperoleh tambahan dana selain dari menjual saham dan meminjam ke bank. Pada penelitian ini, data emis obligasi menjadi variabel independen yang diharapkan berpengaruh terhadap ekspansi usaha dan profitabilitas. Data emisi obligasi diperoleh dari laporan keuangan PT. Pegadaian (persero). emisi obligasi tidak dilakukan setiap tahun, melainkan ada beberapa faktor yang menyebabkan perusahaan untuk melakukan emisi obligasi. PT. Pegadaian (persero) sendiri melakukan emisi obligasi sebanyak 20 kali sejak tahun 1993 dan terakhir pada tahun 2018. Pada penelitian ini, yang menjadi data emisi obligasi hanya 9 tahun terkahir yaitu, 2007, 2009, 2011, 2012, 2013, 2014, 2015, 2017 dan 2018. Berikut adalah total dana penerbitan obligasi PT. Pegadaian (Persero).

Tabel 3

Data Emisi Obligasi PT. Pegadaian (persero)

\begin{tabular}{|c|c|}
\hline $\begin{array}{c}\text { Tahun Emisi } \\
\text { Obligasi }\end{array}$ & $\begin{array}{c}\text { Jumlah Dana Obligasi } \\
\text { (Rupiah) }\end{array}$ \\
\hline 2007 & $600,000,000,000$ \\
\hline 2009 & $1,500,000,000,000$ \\
\hline 2011 & $1,000,000,000,000$ \\
\hline 2012 & $1,000,000,000,000$ \\
\hline 2013 & $1,225,000,000,000$ \\
\hline 2014 & $960,000,000,000$ \\
\hline 2015 & $1,900,000,000,000$ \\
\hline 2017 & $2,500,000,000,000$ \\
\hline 2018 & $2,500,000,000,000$ \\
\hline
\end{tabular}

Sumber: Laporan Keuangan PT. Pegadaian (Persero)

Tabel 4

Hasil Olah Data Statistik Deskriptif Emisi Obligasi

Descriptive Statistics

\begin{tabular}{|l|r|c|c|c|r|}
\hline & $\mathrm{N}$ & Minimum & Maximum & Mean & Std. Deviation \\
\hline EmisiObligasi & & 900000000000. & 2500000000000 & $1,465,000,000,0$ & $691,574,291,02$ \\
Valid N (listwise) & & 00 & .00 & 00.0000 & 0.13330 \\
\hline
\end{tabular}

Sumber: Hasil Pengolahan data SPSS 20, 2020

Dari table di atas dapat dilihat bahwa nilai minimum Emisi obligasi sebesar 600.000.000.000 miliar dan nilai maksimum sebesar 2.500.000.000.000 miliar. Kemudia nilai mean menunjukkan nilai rata-rata emisi obligasi sebesar 1.465.000.000.000 rupiah. 
Nilai standar deviasi sebesar 691.574.291.020 menunjukkan bahwa data pada variabel ini terdistribusi normal.

\section{3) Data Pendapatan Sewa Modal tahun Sebelumnya}

Data pendapatan sewa modal tahun sebelumnya adalah merupakan data yang di transformasi melalui SPSS pada data Pendapatan Sewa Modal PT. Pegadaian (persero) di tahun Emisi Obligasi. Data tersebut disebut dengan data lag. Karena pada transformasi data ini dilakukan dengan rumus Lag. Adapun data pendapatan sewa modal tahun sebelumnya sebagai berikut:

Tabel 5

Data Pendapatan Sewa Modal

\begin{tabular}{|c|c|}
\hline Tahun Emisi Obligasi & $\begin{array}{c}\text { Pendapatan Sewa Modal } \\
\text { (Rupiah) }\end{array}$ \\
\hline 2006 & 0 \\
\hline 2007 & $2,015,965,793,689$ \\
\hline 2019 & $3,609,785,546,431$ \\
\hline 2011 & $5,953,201,577,601$ \\
\hline 2012 & $5,324,946,956,207$ \\
\hline 2013 & $7,201,410,208,148$ \\
\hline 2014 & $7,113,126,058,127$ \\
\hline 2015 & $8,119,794,619,825$ \\
\hline 2017 & $10,353,521,000,000$ \\
\hline
\end{tabular}

Sumber: Data Diolah SPSS, 2020

Tabel 6

Hasil Data Statistik Deskriptif

Pendapatan Sewa Modal Tahun Sebelumnya PT. Pegadaian

\begin{tabular}{|c|c|c|c|c|c|}
\hline \multicolumn{6}{|c|}{ Descriptive Statistics } \\
\hline & $\mathrm{N}$ & Minimum & Maximum & Mean & Std. Deviation \\
\hline & 8 & 2015965793689 & 10353521000000 & $\begin{array}{r}621146897000 \\
3.50\end{array}$ & $\begin{array}{r}261356073012 \\
5.757\end{array}$ \\
\hline Valid N (listwise) & 8 & & & & \\
\hline
\end{tabular}

Sumber: Data Diolah SPSS 20, 2020

Dari table di atas nilai minimum pendapatan modal tahun sebelumnya sebesar Rp 2.015.965.793.689 dan nilai maksimum sebesar Rp 10.353.521.000.000. Kemudian nilai mean menunjukkan bahwa rata-rata pendapatan sewa modal di tahun penerbitan obligasi 
sebesar Rp. 6.221.468.970.003,50. Data pendapatan sewa modal terdistribusi normal karena nilai standar deviasinya lebih kecil dari nilai mean yaitu 2,613,560,730,125.75

\section{b. Estimasi Model Dinamis}

Penelitian ini menggunakan model dinamis, dimana menggunakan senggang waktu pada variabel independen maupun variabel dependen. Apabila variabel tidak bebas dipengaruhi oleh variabel bebas pada waktu t, serta dipengaruhi juga oleh variabel tidak bebas itu sendiri pada waktu t-1 maka model tersebut disebut Autoregressive. Pada penelitian ini variabel dependen waktu sebelumnya mempengaruhi variabel dependen, sehingga menggunakan model Autoregressive dengan pendekatan koyck. Hasil pengujiannya sebagai berikut:

Tabel 7

Hasil Model Autoregressive dengan pendekatan Koyck

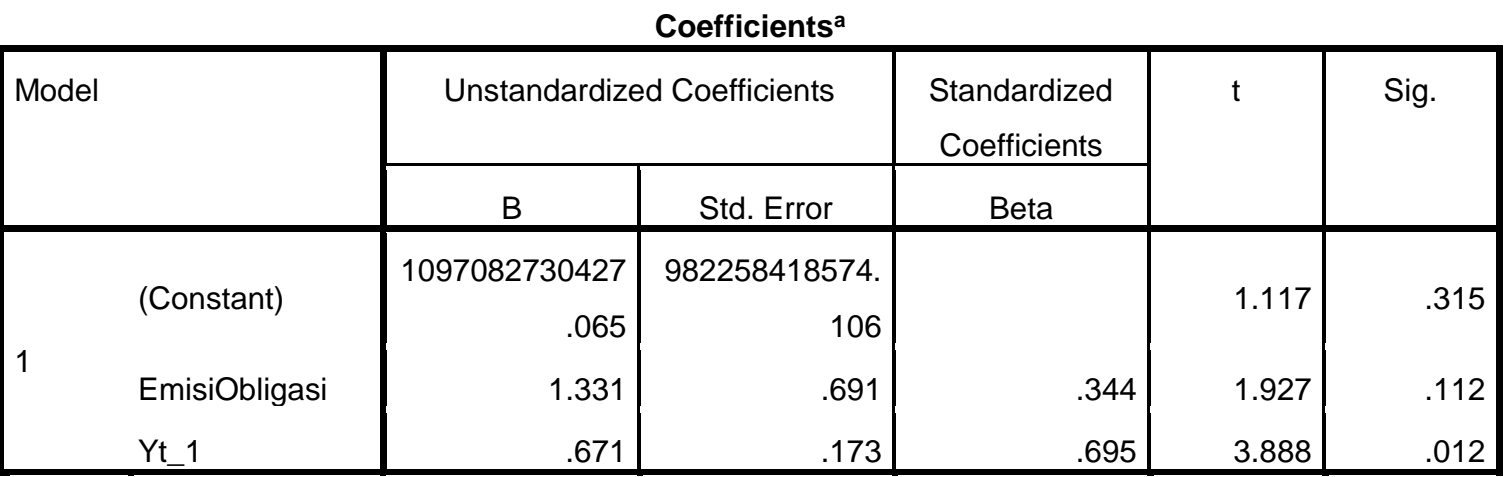

a. Dependent Variable: PendapatanSewaModal

Sumber: Hasil Pengolahan Data SPSS 20, 2020

Dari tabel di atas disimpulkan model dinamis penelitian ini sebagai berikut:

$$
\mathrm{Y}=1097082730427,065+1,331 \mathrm{X}+0,671 \mathrm{Y}_{\mathrm{t}-1}
$$

Dari persamaan diatas, dapat diuraikan :

a. Konstanta persamaan diatas sebesar 1.097.082.730.427,065 artinya jika tidak ada perubahan dari variabel Emisi Obligasi dan pendapatan sewa modal tahun sebelumnya, pendapatan sewa modal pada saat ini sebesar 1.097.082.730.427,065.

b. Koefisien Emisi Obligasi (X) sebesar 1,331 artinya setiap penambahan satu nilai pada Nilai Emisi Obligasi, maka pendapatan sewa modal akan 
mengalami peningkatan sebesar 1,331. Koefisien menunjukkan positif artinya terjadi hubungan searah, apabila ada kenaikan pada nilai emisi obligasi maka pendapatan sewa modal juga akan meningkat.

c. Nilai koefisien pada variabel Pendapatan Sewa Modal tahun sebelumnya (Yt1) sebesar 0,671 yang artinya adalah setiap kenaikan satu pada pendapatan sewa modal pada tahun sebelumnya maka akan meningkatkan pendapatan sewa modal pada saat ini sebesar 0,671. Koefisien menunjukkan positif, menunjukkan bahwa terjadi hubungan searah antara pendapatan sewa modal saat ini dan pendapatan sewa modal tahun sebelumnya.

\section{c. Pengujian Signifikansi Parameter}

Pengujian signifikansi parameter dilakukan secara simultan dengan melihat nilai F statistic dan Koefisien Determinasi. Hasilnya sebagai berikut:

Tabel 8

Pengujian Signifikansi Parameter

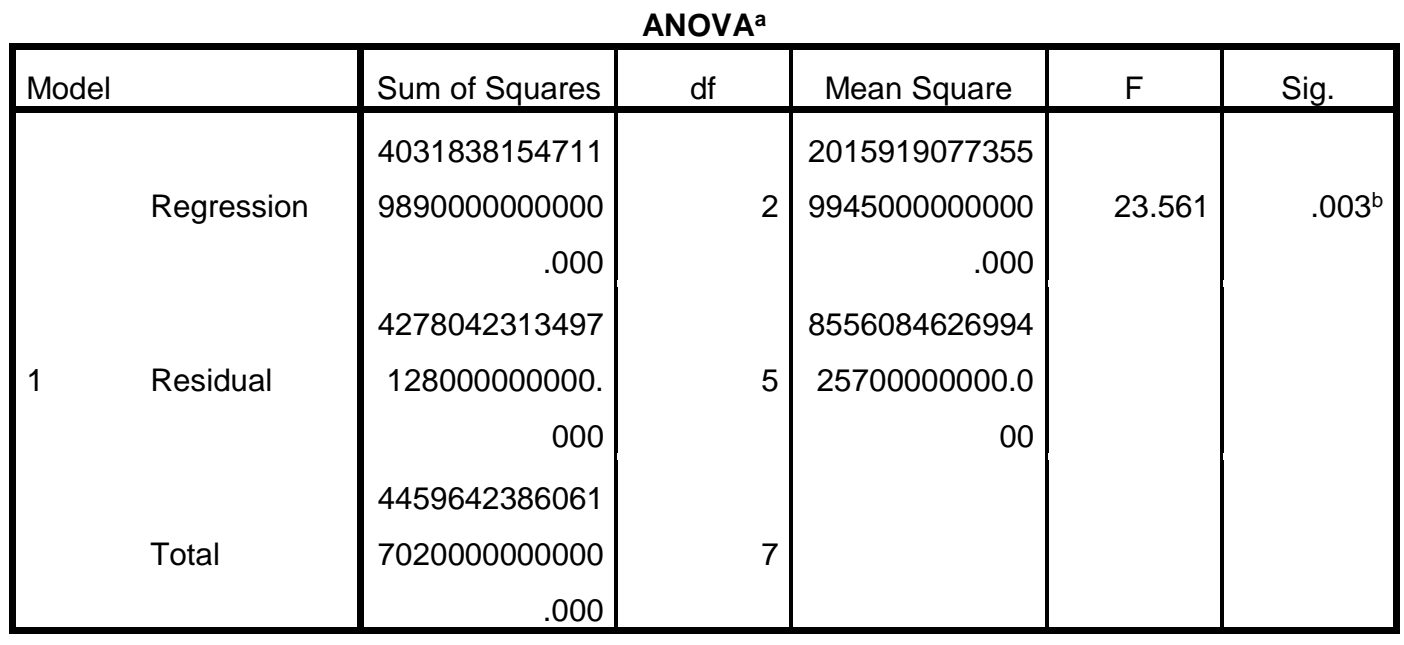

a. Dependent Variable: PendapatanSewaModal

b. Predictors: (Constant), Yt_1, EmisiObligasi

Sumber: Hasil Pengolahan Data SPSS 20, 2020

Dari tabel di atas diperoleh nilai signifikansi pada uji $\mathrm{F}$ sebesar 0,003 artinya lebih kecil dari 0,05. Hal ini menunjukkan bahwa secara keseluruhan variabel yang digunakan untuk melakukan estimasi terhadap variabel $\mathrm{Y}$ berpengaruh positif dan signifikan. Sehingga model Koyck sudah tepat digunakan pada penelitian ini. 
Tabel 9

\section{Hasil Uji Koefisien Determinasi}

\begin{tabular}{|l|r|r|r|r|}
\hline Model & $\mathrm{R}$ & $\mathrm{R}$ Square & $\begin{array}{c}\text { Adjusted R } \\
\text { Square }\end{array}$ & $\begin{array}{c}\text { Std. Error of the } \\
\text { Estimate }\end{array}$ \\
\hline 1 & $.951^{\mathrm{a}}$ & .904 & .866 & $\begin{array}{r}924991060875 . \\
415\end{array}$ \\
\hline
\end{tabular}

a. Predictors: (Constant), Yt_1, EmisiObligasi

Sumber: Data Diolah SPSS, 2020

Selain menggunakan uji $\mathrm{F}$, signifikansi parameter dilakukan dengan uji koefisien determinasi. Nilai koefisien determinasi dilihat dari kolom R Square pada hasil output SPSS pada tabel model Summary. Pada tabel hasil pengolahan data menunjukkan bahwa nilai R square sebesar 0,904 atau 90,4\%. Hal ini menunjukkan bahwa sumbangan variabel emisi obligasi dan pendapatan sewa modal tahun sebelumnya terhadap variabel pendapatan sewa modal pada PT. Pegadaian (Persero) adalah 90,4\% dan sisanya 9,6\% merupakan sumbangan dari variabel lain yang tidak dimasukkan dalam model persamaan dalam penelitian ini

\section{d. Uji Asumsi Klasik}

\section{1) Uji Normalitas}

Pengujian normalitas dilakukan dengan Shapiro - Wilk test. Uji normalitas dengan Shapiro - Wlik test dilakukan untuk mengetahui sebaran data acak suatu sampel kecil. Adapun hasil dari uji ini dapat dilihat pada tabel berikut:

\section{Tabel 10}

\section{Hasil Uji Normalitas Shapiro-Wilk}

Tests of Normality

\begin{tabular}{|c|c|c|c|c|c|c|}
\hline & \multicolumn{3}{|c|}{ Kolmogorov-Smirnov ${ }^{a}$} & \multicolumn{3}{|c|}{ Shapiro-Wilk } \\
\hline & Statistic & Df & Sig. & Statistic & $d f$ & Sig. \\
\hline EmisiObligasi & .203 & 8 & $.200^{*}$ & .836 & 8 & .068 \\
\hline Yt_1 & .135 & 8 & $.200^{*}$ & .986 & 8 & .986 \\
\hline
\end{tabular}

*. This is a lower bound of the true significance.

a. Lilliefors Significance Correction

Dari tabel diatas dapat dilihat nilai sig dari test Shapiro-Wilk untuk variabel Emisi Obligasi dan Pendapatan Sewa Modal tahun sebelumnya sebesar 0,068 dan 0,986 dimana lebih besar daripada 0,005 atau 5\%. Hal ini menunjukkan bahwa data pada penelitian ini terdistribusi Normal. 


\section{2) Uji Autokorelasi}

Uji Autokorelasi pada penelitian ini menggunakan uji Durbin Watson (DW test), adapun hasil uji autokorelasi dari model regresi, sebagai berikut:

Tabel 11

Uji Autokorelasi

\begin{tabular}{|l|r|r|r|r|r|}
\hline Model & $R$ & $R$ Square & $\begin{array}{c}\text { Adjusted R } \\
\text { Square }\end{array}$ & $\begin{array}{c}\text { Std. Error of the } \\
\text { Estimate }\end{array}$ & Durbin-Watson \\
\hline 1 & $.835^{\mathrm{a}}$ & .697 & .654 & $\begin{array}{r}1739936879310 \\
.26100\end{array}$ & 1.331 \\
\hline
\end{tabular}

a. Predictors: (Constant), EmisiObligasi

b. Dependent Variable: PendapatanSewaModal

Sumber: Hasil Pngolahan data SPSS 20, 2020

Dari tabel-tabel diatas dapat diperoleh nilai Durbin Watson pada setiap model regresi. Dapat diketahui bahwa pada model persamaan ini, nilai DW sebesar 1,331. Dimana nilai DW lebih besar daripada dU (1,3199) dan lebih kecil dari 4-dU (2,6801). Sehingga dapat dirumuskan $1,3199<1,331<2,6801$ dan ini menunjukkan bahwa pada model tidak terjadi Autokorelasi.

\section{e. Uji Hipotesis}

Uji T merupakan uji signifikan parameter individual, bertujuan untuk menguji keberartian setiap variabel terhadap variabel dependen, apakah variabel independen mempunyai pengaruh terhadap variabel dependen.

\section{Tabel 12 \\ Hasil Uji T}

\begin{tabular}{|c|c|c|c|c|c|c|}
\hline \multicolumn{7}{|c|}{ Coefficients $^{a}$} \\
\hline \multirow{2}{*}{\multicolumn{2}{|c|}{ Model }} & \multicolumn{2}{|c|}{ Unstandardized Coefficients } & \multirow{2}{*}{$\begin{array}{c}\text { Standardized } \\
\text { Coefficients } \\
\text { Beta }\end{array}$} & \multirow[t]{2}{*}{$\mathrm{t}$} & \multirow[t]{2}{*}{ Sig. } \\
\hline & & $\mathrm{B}$ & Std. Error & & & \\
\hline \multirow{3}{*}{1} & (Constant) & $\begin{array}{r}1097082730427 \\
.065\end{array}$ & $\begin{array}{r}982258418574 . \\
106\end{array}$ & & 1.117 & .315 \\
\hline & EmisiObligasi & 1.331 & 691 & .344 & 1.927 & .112 \\
\hline & Yt_1 & .671 & .173 & .695 & 3.888 & .012 \\
\hline
\end{tabular}

a. Dependent Variable: PendapatanSewaModal 
Dari tabel di atas diperoleh nilai t hitung Emisi Obligasi sebesar 1,927. Menunjukkan bahwa thitung 1,927 < 1,943 tabel. Maka H1 ditolak dan H0 diterima, artinya bahwa Emisi Obligasi tidak berpengaruh signifikan terhadap Pendapatan Sewa Modal pada PT. Pegadaian (Persero). Sedangkan nilai t hitung pendapatan sewa modal di tahun yang lalu memiliki nilai thitung 3,888. Hal ini menunjukkan bahwa t hitung3,888 >1,833 t tabel. Maka H2 diterima dan H0 ditolak.

Maka model persamaan sebagai berikut:

$$
\mathrm{Y}=1 \cdot 097.082 .730 .427,065+1,331 \mathrm{X}+0,671 \mathrm{Y}_{\mathrm{t}-1}
$$

Nilai $a=1.097 .082 .730 .427,065$ artinya jika tidak ada perubahan dari variabel Emisi Obligasi, maka nilai ekpansi usaha yang diukur dengan pendapatan sewa modal sebesar 1.097.082.730.427,065.

NIlai $b=1,331$ artinya setiap penambahan satu nilai pada Nilai Emisi Obligasi, maka pendapatan sewa modal akan mengalami peningkatan sebesar 1,331.

Nilai $\gamma=0,671$ artinya pendapatan sewa modal pada tahun sebelumnya memiliki pengaruh sebesar 0,671 .

Kemudian koefisien bernilai positif artinya terjadi hubungan searah antara penerbitan obligasi terhadap pendapatan sewa modal. Begitupun pada pendapatan sewa modal tahun sebelumnya memiliki pengaruh yang akan datang pada pendapatan sewa modal.

\section{Pembahasan}

Dari hasil penelitian, variabel emisi obligasi tidak berpengaruh terhadap pendapatan sewa modal. Hasil pengujian ini tidak sesuai dengan hipotesis penelitian yang menyatakan bahwa emisi obligasi berpengaruh terhadap pendapatan sewa modal pada PT. Pegadaian (Persero).

Hasil penelitian ini menunjukkan bahwa emisi obligasi yang dilakukan oleh PT. Pegadaian (Persero) tidak berpengaruh terhadap peningkatan pendapatan sewa modal. Tambahan dana yang diperoleh dari emisi obligasi tidak dimaksimalkan untuk peningkatan pendapatan melainkan untuk melakukan refinancing atau pelunasan pinjaman yang sudah mendekati jatuh tempo.

Emisi obligasi yang dilakukan PT. Pegadaian (Persero) bisa jadi berpengaruh secara tidak langsung terhadap pendapatan sewa modal. Karena, dengan adanya tambahan dana dari emisi obligasi yang digunakan untuk refinancing utang, maka modal yang dimiliki perusahaan untuk mencapai target tidak terganggu dengan adanya utang tersebut. Sehingga emisi obligasi mempengaruhi pendapatan sewa modal dalam jangka waktu yang panjang. 
Dengan demikian, emisi obligasi yang dilakukan oleh PT. Pegadaian (Persero) bertujuan untuk melakukan refinancing bukan untuk meningkatkan pendapatan sewa modal, sehingga emisi obligasi tidak berpengaruh terhadapa pendapatan sewa modal.

Sedangkan pendapatan sewa modal tahun sebelumnya memiliki pengaruh positif dan signifikan terhadap pendapatan sewa modal PT. Pegadaian (Peresero). Semakin besar pendapatan sewa modal tahun sebelumnya maka semakin besar pendapatan sewa modal pada saat ini.

Hal ini sejalan dengan teori, dimana tambahan modal dilakukan untuk ekspansi usaha dapat berasal dari dalam perusahaan maupun dari luar perusahaan (Sattar, 2017). Sumber modal internal merupakan modal perusahaan itu sendiri seperti menjual saham, laba ditahan dan juga bisa dari pendapatan perusahaan pada tahun sebelumnya. Sedangkan sumber modal dari luar perushaan merupakan sumber modal yang berasal dari luar perusahaan, seperti menerbitkan obligasi dan pinjaman ke bank (Fahmi, 2014). Kemudian, modal perusahaan digunakan untuk melakukan kegiatan operasional perusahaan baik untuk jangka pendek maupun jangka panjang (Kasmir, 2016). Dengan demikian, pendapatan sewa modal tahun sebelumnya berpengaruh pada pendapatan sewa modal pada saat ini.

\section{SIMPULAN DAN KETERBATASAN}

\section{Simpulan}

Hasilnya menunjukkan bahwa nilai emisi obligasi tidak berpengaruh terhadap pendapatan sewa modal dan pendapatan sewa modal tahun sebelumnya berpengaruh signifikan terhadap pendapatan sewa modal.

\section{Keterbatasan}

a. Penelitian hanya meneliti pada PT. Pegadaian (Perseron), sehingga data yang diteliti sedikit.

b. Sebagai pembanding dapat menggunakan variable lain sehingga dapat mengetahui factor-faktor yang mempengaruhi Pendapatan dari obligasi sehingga hasil penelitian yang lebih baik. 


\section{DAFTAR PUSTAKA}

Archie Marlon Sapulete, \& Manurung, A. H. (2013). November, 1-24.

Basyaib, F. (2016). Manajemen Resiko. Grasindo.

Brigham, E. F., \& Houston, J. F. (2010). Dasar-Dasar Manajemen Keuangan Essentials Of Financial Management. Salemba Empat.

Dilla, A. (2019). Universitas Muhammadiyah Sumatera Utara.

Ekananda, M. (2019). Manajemen Investasi. Penerbit Erlangga.

Fahmi, I. (2014). Manajemen Keuangan Perusahaan Dan Pasar Modal. Mitra Wacana Media.

Fakhruddin, H. M. (2013). Go Public. Elex Media Komputindo.

Harahap, S. H. S. (2020), IAIN Padangsidimpuan.

Hartono, J. (2017). Teori Portofolio Dan Analisis Investasi (Xi). Bpfe-Yogyakarta.

Indonesia, I. B. (2015). Manajemen Resiko 1. Gramedia Pustaka Utama.

Kasmir. (2011). Analisis Laporan Keuangan. Rajawali Pers.

Kuncoro, M. (2013). Metode Riset Untuk Bisnis dan Ekonomi Bagaimana Menelti dan Menulis Tesis. Erlangga.

Maimunah, M. (2018). Pengaruh penerbitan obligasi syariah (sukuk) Dan reksa dana syariah terhadap Profitabilitas bank syariah mandiri.

Muchtar, P. D. B., Rahmidani, \& Kurnia Siwi (2016). Bank dan Lembaga Keuangan Lain. Kencana.

Mulazid, D. A. S. (2016). Kedudukan Sistem Pegadaian Syariah.

Putri, Rianda Ajeng Ardiyanti \& Herlambang, L. (2015). Pengaruh Penerbitan Sukuk Ijarah terhadap ROA, ROE dan Earning Per Share Emiten di BEI Tahun 2009-2013. Jurnal JESTT, 2(6), 459-472.

Ramadhani, I. (2013). Pengaruh Penerbitan Obligasi Syariah Terhadap Profitabilitas. Etikonomi, 12(2), 149-164. https://doi.org/10.15408/etk.v12i2.1914

Sattar. (2017). Buku Ajar Pengantar Bisnis. Deepublish.

Sugiyono. (2014). Metode Peneltian Kuantitatif, Kualitatif dan $R \&$ D. Alfabeta.

Sujarweni, W. V. (2018). Statistik untuk bisnis dan ekonomi. pustaka baru press.

Wardhono, A., Indrawati, Y., Gema Qoriah, C., \& Nasir, M. A. (2019). Analisis Data Time Series dalam Model makroekonomi. CV. Pustaka Abadi.

YAP, P. (2017). Manajemen Resiko Perusahaan. Growing Publishing. 